Note

\title{
BIOLOGY OF Microctonus sp. (HYMENOPTERA: BRACONIDAE), A PARASITOID OF Cyrtomon luridus BOH. (COLEOPTERA: CURCULIONIDAE)
}

\author{
Paulo Tironi ${ }^{1 *}$; Adrian von Treuenfels ${ }^{1}$; José Roberto Postali Parra ${ }^{2}$ \\ ${ }^{1}$ Solana Agropecuária Ltda, C.P. 01 - 86700-970 - Arapongas, PR - Brasil. \\ ${ }^{2}$ USP/ESALQ - Depto. de Entomologia, Fitopatologia e Zoologia Agrícola, C.P. 9 - 13418-900 - Piracicaba, SP - \\ Brasil. \\ *Corresponding author <tironi@sao.boehringer-ingelheim.com>
}

\begin{abstract}
Cyrtomon luridus (Boh.), a native insect of wild Solanaceae, has adapted to the medicinal plant Duboisia sp., introduced from Australia, causing damages up to $100 \%$ mortality. Microctonus sp. is the most important natural enemy of $C$. luridus and its potential for biological control was investigated in this work. This study was carried out in Arapongas, Paraná State, Brazil, from 1994 to 1996. Parasitism of C. luridus by Microctonus sp. was highest from February through June (maximum of 54\% in May 1996), when the $C$. luridus adult population was decreasing. The female sex ratio of Microctonus sp. under natural conditions was 0.57 to 0.69 , which was close to 1 male : 2 female. Production of males occurs parthenogetically (arrhenotoky). In the laboratory, parasitism reached $40 \%$ when two adult $C$. luridus were exposed per parasitoid. The number of Microctonus sp. adults that emerged per parasitized beetle ranged from 4.7 to 14.2. Larvalpupal viability was 31.7 to $64.8 \%$ and the female sex ratio ranged from 0.0 to 0.37 , with prevalence of males. The egg-pupal period was 12.7 days and the pupal-adult period was 10.7 days, resulting in a mean life cycle (egg-adult) of 22.4 days for this parasitoid $\left(25^{\circ} \mathrm{C}, 70 \%\right.$ R.H.). This is the first report of a new species of Microctonus sp. in C. luridus.

Key words: biological control, parasitism, medicinal plant, duboisia

\section{BIOLOGIA DE Microctonus sp. (HYMENOPTERA: BRACONIDAE), PARASITÓIDE DE Cyrtomon luridus BOH. (COLEOPTERA: CURCULIONIDAE)}

RESUMO: Cyrtomon luridus (Boh.) é um inseto nativo de solanáceas silvestres e se adaptou à planta medicinal Duboisia sp., introduzida da Austrália, causando danos de até $100 \%$ de mortalidade. Microctonus sp. é o mais importante inimigo natural de C. luridus e seu potencial para o controle biológico foi investigado neste trabalho. Os experimentos foram conduzidos em Arapongas, Estado do Paraná, de 1994 a 1996. O parasitismo de C. luridus, por Microctonus sp. foi maior nos meses de fevereiro a junho (máximo de 54\% em maio/96), coincidindo com a diminuição da população de adultos de C. luridus. A razão sexual de fêmeas de Microctonus sp., em condições naturais, foi de 0,57 a 0,69; sem cópula há produção de machos (partenogênese arrenótoca). Em laboratório, o parasitismo chegou a 40\%, quando se ofereciam 2 adultos de C. luridus para 1 parasitóide. O número de adultos de Microctonus sp. por besouro parasitado variou de 4,7 a 14,2; a viabilidade larvalpupal de 31,7 a 64,8\% e a razão sexual de 0 a 0,37, com predominância de machos. O período ovo-adulto foi em média, de 22,4 dias, sendo 12,7 dias para o período ovo-pupa e 10,7 dias para o período pupa-adulto (a $25^{\circ}$ C; 70\% de U.R). Estes foram os primeiros resultados da biologia desta nova espécie de Microctonus, parasitóide com potencial a ser avaliado para o controle biológico de C. luridus.

Palavras-chave: controle biológico, parasitismo, planta medicinal, duboisia

\section{INTRODUCTION}

Species belonging to the genus Cyrtomon occur in Neotropical regions, and in Brazil, Cyrtomon luridus (Boheman) has been recorded in the States of Paraná,
Santa Catarina and Rio Grande do Sul (Lanteri, 1990). This weevil develops in wild Solanaceae (wild tobacco, coerana, etc.), as well as on cotton and eucalyptus (Sérgio A. Vanin $\left.{ }^{1}\right)$. C. luridus is a univoltine insect; its larvae feed on roots and adults consume leaves of plants. It has

${ }^{1}$ Dr. Sérgio A. Vanin - University of São Paulo, personal communication.

Sci. Agric. (Piracicaba, Braz.), v.61, n.5, p.538-541, Sept./Oct. 2004 
adapted to and seriously damages a medicinal plant, Duboisia sp. (Solanaceae) (hybrids between $D$. myoporoides and D. leichhardtii) (Ohlendorf, 2002), causing up to $100 \%$ mortality. Introduced from Australia, this plant is rich in scopolamine, an alkaloid widely used for human and animal health.

Cyrtomon luridus adults collected from Duboisia sp., in Arapongas, Paraná State, were found parasitized by the braconid wasp, Microctonus sp. (Hymenoptera: Braconidae). Species of this genus are known as solitary endoparasitoids of adult weevils of the genera Hypera and Sitona (Morales \& Hower, 1981, Goldson et al., 1990), Listronotus (Goldson et al., 1992), Trichobaris (Cuda \& Burke, 1991) and possibly Naupactus and Pantomorus (Gravena et al., 1992). Because this weevil causes extensive damage to Duboisia sp., research was undertaken to investigate the biology and ecology of Microctonus sp. in the aim to evaluate its potential for the biological control of $C$. luridus.

\section{MATERIAL AND METHODS}

Adults of C. luridus were collected in the field from Duboisia sp., from February 1994 to June

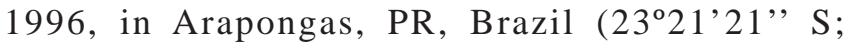
$51^{\circ} 29^{\prime} 27^{\prime \prime} \mathrm{W}$ ). Individual insects were placed in rearing containers (200-mL plastic cups), covered with plastic (PVC) film, along with Duboisia sp. leaves as a food source. The containers were maintained in the laboratory $\left(25 \pm 2^{\circ}\right.$ C.; R.H. $70 \pm 10 \%$; $12 \mathrm{~h}$ photo phase), to determine the degree of parasitism. The female sex ratio [s.r. $=$ females $/$ (males + females)] of Microctonus sp. that emerged from the adult weevils was calculated.

Parasitoids and adults of $C$. luridus were maintained in the same Duboisia sp. containers described above. They were exposed to adult Microctonus sp. to determine the parasitism rates. In this case, the ratio of adult C. luridus per Microctonus sp. female ranged from 1 to 3, with continuous host exposure until death of the parasitoid occurred. The number of replications ranged from 20 to 184, depending on the number of parasitoids available.

Larva-pupal viability, number of parasitoids that emerged per parasitized beetle, female sex ratio in the laboratory and the duration of the life cycle (egg to adult) in Microctonus sp., were obtained by examining progeny daily. The superparasitism or polyembriony were not the object of this study. The type of reproduction of Microctonus sp. was determined by examining the sex ratio of progeny of previously mated (during 24h) or unmated females with 30 replications, and data presented as average \pm standard deviation.

\section{RESULTS AND DISCUSSION}

The rate of parasitism of C. luridus by Microctonus sp. under field conditions ranged from 0 to 54\%, from February 1994 to June 1996. Parasitism rates were higher from February to June, when adult populations of C. luridus on Duboisia sp. were low, compared to October to January (Figure 1). The highest parasitism rate occurred in May 1996 (54\%), in areas with taller plants (about $2.0 \mathrm{~m}$ ) and fully developed foliage, which apparently is a preferred habitat of Microctonus sp. The best time to introduce the parasitoid probably depends on the development stage of Duboisia, which was not investigated in this study. However, at the final phase of emergence of adult $C$. luridus, the parasitism rate was not high enough to avoid economic damage to Duboisia sp. If this parasitoid is to be mass-reared in the laboratory, it probably should be released in the field in September, when adults begin to emerge, in order to maximize the degree of control. In isolated areas containing trap plants left as refuges for the weevils to be controlled with insecticides, there was no parasitism. Therefore, parasitoid releases should be avoided in areas subjected to chemical control practices.

The parasitism pattern observed in Brazil is typical of Microctonus sp. In New Zealand, Goldson et al. (1990) found $85-100 \%$ infestation by Microctonus aethiopoides (Loan) in beetles remaining from an annual generation of Sitona discoideus (Gyllenhal), with minimal parasitism when new beetles emerged. The lack of oviposition by the parasitoid during the winter (overwintering diapause) resulted in minimal parasitism in August and September. In addition, Goldson et al. (1998) observed in New Zealand three generations per year of Microctonus hyperodae (Loan), which were produced in Listronotus bonariensis (Kuschel) after diapause in September. In this case, the maximum parasitism rate reached $90 \%$ in March, decreasing rapidly in April, with the appearance of new adults from neighboring fields free of parasitoids. This conclusion supports the suggestion to release Microctonus sp. in September to control C. luridus. However, more studies are necessary. In contrast, Copley \& Grant (1998) observed

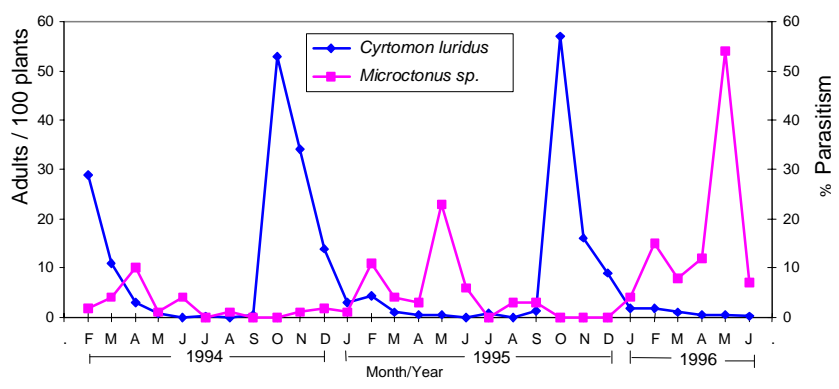

Figure 1 - The parasitism rates of Microctonus sp. in the Cyrtomon luridus population on Duboisia sp. under field conditions. 
poor colonization by M. aethiopoides introduced for the control of Hypera postica (Gyllenhal) in alfalfa fields in Tennessee, USA. Barratt et al. (1997) obtained only a maximum parasitism rate of $6.0 \%$ in Sitona lepidus (Gyllenhal) by M. aethiopoides or M. hyperodae in laboratory cage tests, indicating that these species would be ineffective for the biological control of this pest in New Zealand pastures.

The sex ratio of Microctonus sp. under natural conditions was from $0.57 \pm 0.11$ to $0.69 \pm 0.10$, which is close to 1 male : 2 female, very close to $0.60-0.65$ found in the nature in M. aethiops (Nees) (= aethiopoides Loan) by Fusco \& Hower (1974). In the laboratory, the sex ratio ranged from $0.16 \pm 0.13$ to $0.37 \pm 0.13$ (Table 1), with a predominance of male parasitoids. Therefore, rearing conditions were probably inadequate for normal mating or the continuous oviposition produced more males, as demonstrated by Fusco \& Hower (1974). Beetles parasitized by unfertilized females of Microctonus sp. produced only males. Therefore, reproduction in Microctonus sp. can be sexual or by arrhenotokous parthenogenesis, a common occurrence in hymenoptera.

The maximum parasitism rate in the laboratory was $40 \%$ in May/95 (Table 2), when two adults C. luridus were placed with one female Microctonus sp. in each rearing chamber. However, parasitism rates of 30.7, 19.5 and $20.7 \%$ were obtained in July/95 with the same 2:1 ratio. In general, the percentage of parasitism for this host/parasitoid ratio was higher than that obtained with 1:1 (33\% and 32\%, respectively) or 3:1 (19\%), both of them resulting in a low level of parasitism. In all cases, C. luridus attempted to avoid attack by the parasitoid by moving the last pair of legs. Premature mortality of the infested beetles also was observed. Premature mortality is a typical result from superparasitism, which is common in arrhenotokous parasitoids, but it was not the object of this study. However, premature mortality also can be caused by bacterial transmission from the invasion of pathogens in the wounds produced by Microctonus oviposition (Jackson \& McNeill, 1998).

Overall, parasitism of $C$. luridus by Microctonus sp. in this study was lower than results found by other authors, who investigated different species and host/ parasitoid densities. In the New Zealand, the mean parasitism rate of L. bonariensis by Microctonus hyperodae was $58.7 \%$ (Goldson et al., 1993), with a ratio of 40 beetles : 1 female parasitoid. Fusco \& Hower (1974) found a maximum parasitism of $51.6 \%$ when Hypera postica was parasitized by $M$. aethiops with 50:1 ratio, with a low percentage of premature mortality.

The mean number of adult Microctonus sp. that emerged from each parasitized $C$. luridus ranged from 4.7 \pm 1.9 to $14.2 \pm 8.0$, corresponding to a larva-pupa viability from $31.7 \pm 9.9 \%$ to $64.8 \pm 20.4 \%$ (Table 1 ). The larvae of Microctonus sp. change into pupae protected by cocoons, after they leave the beetles. The mean duration of the full cycle (egg-adult) was $22.4 \pm 1.1$ days, including 11 to 14 days (mean of $12.7 \pm 1.1$ days) for the eggpupa period, and 9 to 13 days (mean $10.7 \pm 0.95$ days) for the pupa-adult period. These values were very close to those found by Goldson et al. (1993), who reported a life cycle of 22.4 days for $M$. hyperodae raised on $L$. bonariensis, although variations in fecundity can be different according to habitats, exposure to the host and genetically distinct populations (Phillips et al., 1996; Winder et al., 1997).

Difficulties with mass rearing of Microctonus sp. for release in the field are the main limiting factor for using this parasitoid for augmentative biological control of C. luridus. An artificial diet for C. luridus would facilitate the rearing of this parasitoid. Also, a successful biological control program with Microctonus sp. may depend on the timing of release (at the time of the first appearance of $C$. luridus adults) (Figure 1).

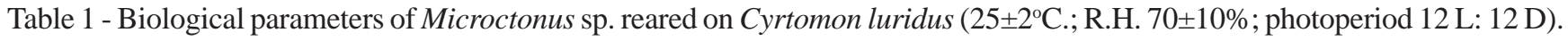

\begin{tabular}{lcccccc}
\hline Origin of the parasitoid & Date & \% parasitism & $\begin{array}{c}\text { Adults of Microctonus sp. } \\
\text { / parasitized beetle }\end{array}$ & $\begin{array}{c}\text { Pupa-larva } \\
\text { Viability }\end{array}$ & $\begin{array}{c}\text { Female Sex } \\
\text { Ratio }\end{array}$ & $\begin{array}{c}\text { Beetles: } \\
\text { parasitoid ratio }\end{array}$ \\
\hline & & $\%$ & & $\%$ & & \\
laboratory & March/95 & 19.0 & $8.5 \pm 2.5$ & $45.0 \pm 10.5$ & $0.37 \pm 0.13$ & $3: 1 \mathrm{n}^{1}=184$ \\
laboratory(virgin females) & March/95 & 33.0 & $14.2 \pm 8.04$ & $63.3 \pm 17.8$ & 0.0 & $1: 1 \mathrm{n}=30$ \\
laboratory & May/95 & 32.0 & $8.1 \pm 3.5$ & $45.3 \pm 13.7$ & $0.22 \pm 0.18$ & $1: 1 \mathrm{n}=50$ \\
laboratory & May/95 & 40.0 & $8.4 \pm 2.7$ & $64.8 \pm 20.4$ & $0.23 \pm 0.15$ & $2: 1 \mathrm{n}=20$ \\
laboratory & May/95 & 30.7 & $4.7 \pm 1.9$ & $31.7 \pm 9.9$ & $0.21 \pm 0.12$ & $2: 1 \mathrm{n}=75$ \\
laboratory & June/95 & 19.5 & $7.8 \pm 2.5$ & $44.7 \pm 9.8$ & $0.16 \pm 0.09$ & $2: 1 \mathrm{n}=136$ \\
laboratory & July/95 & 20.7 & $9.7 \pm 2.7$ & $47.8 \pm 7.6$ & $0.34 \pm 0.1$ & $2: 1 \mathrm{n}=138$ \\
field & March/95 & -- & $12.7 \pm 4.51$ & $59.6 \pm 12.1$ & $0.61 \pm 0.13$ & $\mathrm{n}=27$ \\
field & May/95 & -- & $6.3 \pm 2.5$ & $41.7 \pm 11.3$ & $0.57 \pm 0.11$ & $\mathrm{n}=40$ \\
field & July/95 & -- & $11.0 \pm 4.1$ & $50.7 \pm 11.6$ & $0.69 \pm 0.10$ & $\mathrm{n}=25$ \\
\hline
\end{tabular}

${ }^{1} \mathrm{n}=$ number of observations. 
Table 2 - Parasitism of Cyrtomon luridus by Microctonus sp., at different host : parasitoid ratios, under laboratory conditions. $\left(25 \pm 2^{\circ} \mathrm{C}\right.$; R.H. $70 \pm 10 \%$; photoperiod $12 \mathrm{~L}$ : $12 \mathrm{D}$ ).

\begin{tabular}{lcccc}
\hline Ratio Pest : parasitoid & Parasitism & Replications & Date \\
\hline & $\%$ & $n$ & \\
\hline beetles $: 1$ female & 19.0 & 184 & March/95 \\
2 beetles $: 1$ female & 40.0 & 20 & May/95 \\
\hline 2 beetles $: 1$ female & 30.7 & 75 & May/95 \\
2 beetles $: 1$ female & 19.5 & 136 & June/95 \\
2 beetles $: 1$ female & 20.7 & 138 & July/95 \\
1 beetles $: 1$ female & 33.0 & 30 & March/95 \\
1 beetles $: 1$ female & 32.0 & 50 & May/95 \\
\hline
\end{tabular}

\section{ACKNOWLEDGEMENTS}

We thank Dr. Robert A. Wharton of Texas A\&M University for determining the genus of the parasitoid (it is a new species, and a descriptive publication is being prepared by the author). We also thank the laboratory assistants who helped with the experiment. This study was supported by Boehringer Ingelheim, through Fundação de Estudos Agrários Luiz de Queiroz - Universidade de São Paulo, Piracicaba, SP - Brazil.

\section{REFERENCES}

BARRATT, B.I.P.; EVANS A.A.; FERGUSON, C.M.; O'CALLAGHAN, M. Potential for biocontrol of Sitona lepidus Gyllenhal by Microctonus spp. In: NEW ZEALAND PLANT PROTECTION CONFERENCE, 15., Canterbury, 1997. Proceedings. Canterbury: Lincoln University, 1997. p.37-40.

COPLEY, K.J.; GRANT, J.F. Statewide distribution of parasitoids of the alfalfa weevil in Tennessee. Journal of Agricultural Entomology, v.15, p.43-51, 1998

CUDA, J.P.; BURKE, H.R. Biology of Trichobaris bridwelli (Coleoptera: Curculionidae, a possible agent for the biological control of Datura stramonium (Solanaceae). Environmental Entomology, v.20, p.899908, 1991.

FUSCO, R.A.; HOWER, JR., A.A. Influence of parasitoid-host density and host availability on the laboratory propagation of Microctonus aethiops (Hym.: Braconidae) parasitoid of Hypera postica (Coleop.: Curculionidae). Entomophaga, v.19, p.75-83, 1974.
GOLDSON, S.L.; PROFFITT, J.R.; McNEILL, M.R. Seasonal biology and ecology in New Zealand of Microctonus aethiopoides (Hymenoptera: Braconidae), a parasitoid of Sitona spp. (Coleoptera: Curculionidae), with special emphasis on atypical behaviour. Journal of Applied Ecology, v.27, p.703-722, 1990.

GOLDSON, S.L.; PROFFITT, J.R.; BAIRD, D.B. Establishment and phenology of the parasitoid Microctonus hyperodae (Hymenoptera: Braconidae) in New Zealand. Environmental Entomology, v.27, p.1386-1392, 1998.

GOLDSON, S.L.; McNEILL, M.R.; PHILLIPS, C.B.; PROFFITT. J.R. Host specificity testing and suitability of the parasitoid Microctonus hyperodae (Hymenoptera: Braconidae, Euphorinae) as a biological control agent of Listronotus bonariensis (Coleoptera: Curculionidae) in New Zealand. Entomophaga, v.37, p.483-498, 1992.

GOLDSON, S.L.; McNEILL, M.R.; PROFFITT, J.R.; BARKER, G.M.; ADDISON, P.J.; BARRATT, B.I.P.; FERGUSON, C.M. Systematic mass rearing and release of Microctonus hyperodae (Hymenoptera : Braconidae, Euphorinae), a parasitoid of the argentine stem weevil Listronotus bonariensis (Col.: Curculionidae) and records of its establishment in New Zealand. Entomophaga, v.38,p.527-536, 1993.

GRAVENA, S.; CORREIA, A.C.B.; YAMAMOTO, P.T.; MUNUERA, M.C.M.; SALVA. R.A. Pantomorus \& Naupactus, uma ameaça a citricultura. Jaboticabal; CEMIP, UNESP, 1992. 9p. (Boletim Técnico, 2).

JACKSON, T.A.; McNEILL, M.R. Premature death in parasitized Listronotus bonariensis adults can be caused by bacteria transmitted by Microctonus hyperodae. Biocontrol Science Technology, v.8, p.389396, 1998.

LANTERI, A.A. Revision sistemática del género Cyrtomon Schönherr (Coleoptera, Curculionidae). Revista Brasileira de Entomologia, v.34, p.387-402, 1990.

MORALES, J.; HOWER A.A. Thermal requirements for M. aethiopoides. Environmental Entomology, v.10, p.279-284, 1981.

OHLENDORF, W. Domestication and crop development of Duboisia spp. (Solanaceae). <http://www.fao.org/docrep/w3735e/w3735e23.htm> (08 out. 2002).

PHILLIPS, C.B.; BARKER, G.M.; ROBERTS, R.L.; McNEILL, M.R GOLDSON S.L.; O'CALLAGHAN, M. Fecundity of wild and laboratory reared ecotypes of Microctonus hyperodae Loan (Hymenoptera: Braconidae). In: NEW ZEALAND PLANT PROTECTION CONFERENCE, 14., Forty Ninth, 1996. Proceedings. Nelson: New Zealand, 1996. p.285-290.

WINDER, L.M.; GOLDSON, S.L.; WILLIAMS, C.L.; O’CALLAGHAN M. Genetic variation between two Microctonus hyperodae populations imported for control of Argentine stem weevil. In: NEW ZEALAND PLANT PROTECTION CONFERENCE, 15., Canterbury, 1997. Proceedings. Canterbury: Lincoln University, 1997. p.333-337. (Footnotes)

$\overline{\text { Received August }}$ 01, 2003

Accepted July 07, 2004 